\title{
Conceptualizing the True Nature of Cost: Agriculture, Education and Falling in Love
}

\author{
Ellerbrock $\mathbf{M}^{*}$ \\ Department of Agricultural \& Applied Economics, College of Agriculture \& Life Sciences, USA
}

Submission: April 26, 2018; Published: June 26, 2018

*Corresponding author: MEllerbrock, Agricultural \& Applied Economics Department, College of Agriculture \& Life Sciences, Virginia Tech, USA, Tell: (540) 231-7722; Email: mebrock@vt.edu

\section{Abstract}

Cost is a complex concept, with several dimensions. Students need to distinguish between the seller's cost of production versus the buyer's cost of acquisition. Applied to agriculture, education and falling in love, classical microeconomic theory principles are used to demonstrate two critical realities: acquisitions costs are a function of Opportunity Costs, which accelerate with successive units of consumption.

Keywords: Agriculture; Classical microeconomic theory; Consumption; Opportunity Cost; Monetary units; Pecuniary; Consciously; Unconsciously; Hypothetical situations; Purchase decision

\section{Introduction}

Every economics textbook begins by defining economics as the study of the necessity to make choices whenever resources are scarce, which is almost always the case [1,2]. In this reality of life, making wise choices is a challenge, particularly when estimating the true costs of our options. A key factor is Opportunity Cost.

It has been said that a college course in economics is a success if it teaches students only one thing: the true nature of cost. For example: how much does it truly cost to own a combine, have a baby, attend college? Total Costs of college would obviously include Direct Expenses of tuition (e.g., \$15,000 per year), plus Indirect Expenses of room and board (e.g., an additional $\$ 10,000$ per year), but also the Opportunity Cost of not choosing one's next best option (e.g., staying home and earning $\$ 30,000$ selling farm equipment for John Deere, Inc.) ... for a total annual investment of $\$ 55,000$ to attend college. To spend $\$ 25,000$ versus earn $\$ 30,000$ is a $\$ 55,000$ decision.

Though invisible, Opportunity Costs (foregone income while in school) are real [3]. The true cost of something is determined by what we give up getting it, usually expressed in monetary units.

\section{Methods}

Historically more practical than barter, paper money (currency) has no inherent value of its own. It serves two basic roles. First, money helps consumers compare trade-offs among various options while shopping. Second, it then facilitates exchange between buyers and sellers by serving as a common measuring stick. When money changes hands in the marketplace, it is called a "pecuniary" transaction, from the Latin "pecus," which means cow or cattle-ancient media of exchange.

What is the value today of a $\$ 10$ bill, or $\$ 20, \$ 50, \$ 100$ ? Answer: what it will purchase. At a point in time, its value depends on one's second best choice of purchasing options. A difficult concept for some to grasp, it reflects everyday behavior. When deciding whether to spend $\$ 10$ on item $A$ in a store, we ask (consciously or unconsciously) ourselves, "What is the next best thing I could purchase with my money, now or in the future?"

If there are lots of enticing choices available, it becomes difficult to choose how to spend the $\$ 10$, particularly if the next best choice (item B) offers utility nearly as great as item A. Conversely, if few options exist, the choice is easier. If no options other than item A exist now or in the future (e.g., earning interest on savings), then the only rational choice is to purchase item A. In that case, the true cost of item $A$ is zero because one sacrifices nothing to obtain it.

For another way to think about it, consider two hypothetical situations. When playing a board game with fake money, you might as well spend it, since it is worthless once the game ends. The same would be true when shopping with a foreign currency while on an international cruise if, for some reason, unspent foreign currency could not be converted back into U.S. dollars. If several foreign souvenirs appeal to you, then the "cost" of your top choice (item $\mathrm{A}$ ) is the next best choice you do not purchase 
(item B). If only one item appeals to you, then it is costless. If you do not buy it, you forfeit the temporary purchasing power of your foreign currency or play money. Though hypothetical, the cases illustrate a real fact of economic life: the true cost of anything is what one gives up, now or in the future, to obtain it.

A downward-sloping Demand Curve reflects a consumer's "Willingness to Pay" (WTP) for various quantities of a good or service at various prices per unit, based on its perceived marginal utility per unit consumed. A Market Demand Curve sums the WTP of all potential consumers for that item [4].

Frequently confused with "price" is "cost," e.g., asking a sales clerk, "How much does this feed ration cost?", when the shopper actually means, "What is the price of this item?" The cost of production paid by the seller versus the acquisition cost (i.e., price) consumers are WTP are two different things. Just because something may cost a lot to produce does not mean that consumers are WTP a high price for it, e.g., robotic milking parlor. Production costs, plus a minimum desired level of profit, are reflected in the seller's upward-sloping Supply Curve, i.e., "Willingness to Accept" (WTA).

However, as discussed above, the price consumers are WTP reflect the Opportunity Costs of foregoing other options, based on their relative utility. In other words, how much more or less utility could I purchase with my best alternative choice? The answer will drive the final purchase decision.

In sum, consumers are WTP a stated price for an item as long as its expected marginal utility equals or exceeds the true cost of purchasing it, including Opportunity Costs-what else one could do with their money. When WTP is higher than the actual price paid, the excess value (unpaid for utility) is termed "Consumer Surplus" (CS). When the actual price paid is higher than WTA, the excess revenue received is termed "Producer Surplus" (PS). See Figure 1.

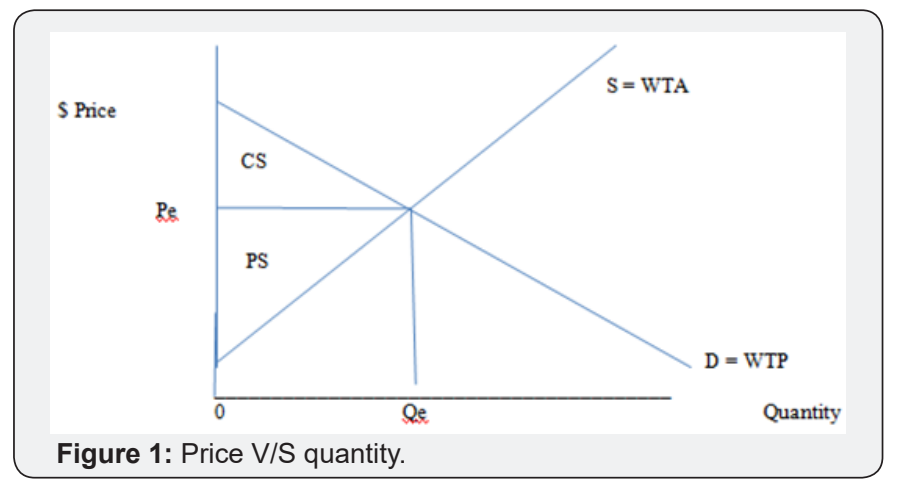

Economists use Production Possibility Frontiers (PPF) to illustrate that costs involve trade-offs and make a critical point about the magnitude of Opportunity Costs [5]. In Macroeconomics, every nation must choose its optimal combination of civilian and/or military goods, such as point B, C, D or E in Figure 2, depending on the highest point of tangency on the PPF and that nation's Budget Constraint (not shown).
Similarly, in Microeconomics, an individual farmer must select the optimal combination of corn and/or wheat to grow, given her/his set of inputs. Point A represents economic inefficiency, i.e., not getting as much output as possible from its limited inputs. Conversely, Point F represents scarcity, i.e., there are not currently enough inputs to produce that many outputs. With technological advancement, economic growth shifts the entire curve outward (Figure 2).

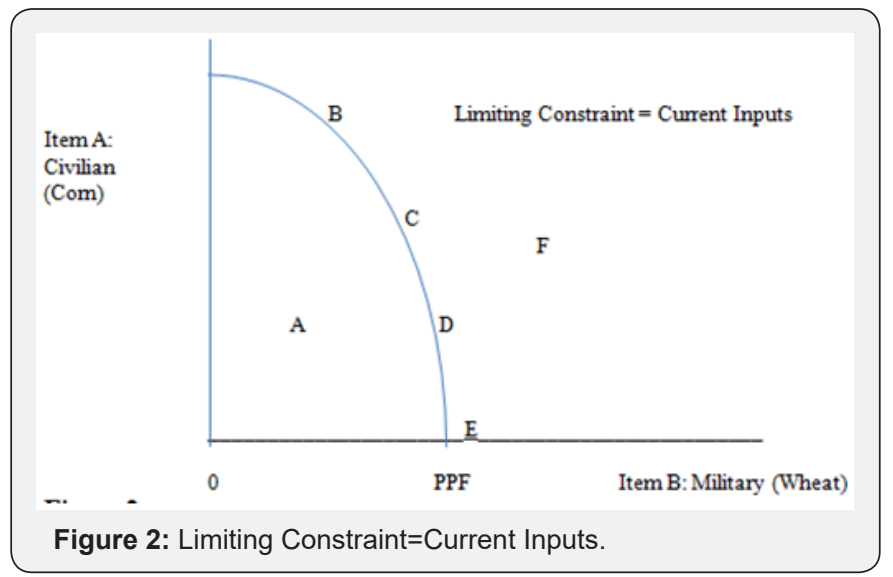

The concave (to the origin) shape of the PPF is critical. It reflects the unfortunate reality of increasing Opportunity Costs. As we produce successive units of Item A, we forego increasing amounts of Item B (see Figure 3 below). Note the horizontal losses of Item B as we produce successive units of Item A ... moving from points $B$ to $C$ to $D$ to $E$ to $F$ to $G$ to $H$, and vice versa if we move down the PPFs. Conversely, a convex PPF would be Utopian-as we produce more and more of Item A, we would sacrifice less and less of Item B ... seldom the case on Planet Earth!

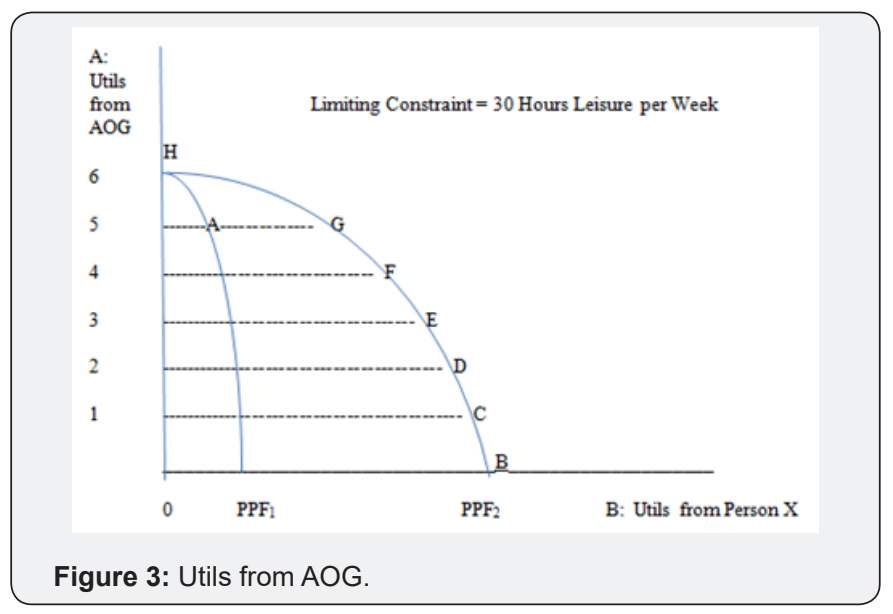

\section{Results and Discussion}

The reality of increasing Opportunity Costs is personal, as well as professional. For example, how much does it "cost" to fall in love? In Figure 3, a Util is one bucket of utility, happiness, satisfaction. Person $X$ is initially a new acquaintance (PPF1). AOG represents All Other Guys/Girls=one's existing family and friends. In that case, one would spend most or all (Point A) of 
their leisure time with AOG because spending time with Person $\mathrm{X}$ generates little utility.

What happens if they fall in love and Person $\mathrm{X}$ becomes a fiancé'/spouse (PPF2)? Obviously, the horizontal intercept shifts outward, i.e., the joy of being in love. Note that the vertical intercept does not shift because one's feelings for their existing family and friends have not changed. Nevertheless, the optimal amount of time spent with AOG versus Person X will likely shift from Point A toward Point B because AOG have become more "expensive" to be with, regardless of how much they are still loved, oftentimes leading to guilt trips from resentful/jealous family and friends. In response, as one desperately seeks successive Utils from AOG to maintain peace in those relationships, note that the horizontal sacrifice (Opportunity Costs) from being apart from Person X are now greater under PPF2 than PPF1. Absence makes the heart grow fonder!

\section{Summary}

Educators need to help students understand that the reality of increasing Opportunity Costs applies to all human endeavors. If one strives to win a Nobel Prize in Economics, Gold Medal in the Olympics, become $1^{\text {st }}$ Chair violinist in the Boston Symphony or play in the NBA - all noble pursuits, one should at least recognize that the costs of seeking excellence/perfection accelerate. The more and more we do of anything, the more expensive it becomes. Whether it is romantic love or loving work, having children, playing music, sports, reading, traveling or any avocation, falling in love is not free.

\section{References}

1. Casavant et al. (1999) Agricultural Economics and Management. Upper Saddle River, NJ: Prentice Hall.

2. Cramer GL, Jenson CW (1991) Agricultural Economics and Agribusiness. $5^{\text {th }}$ edn. NY: John Wiley and Sons, Inc, New York.

3. Penson et al. (2002) Introduction to Agricultural Economics. $3^{\text {rd }}$ edn Upper Saddle River, NJ: Prentice Hall.

4. Mateer et al. (2016) Essentials of Economics. NY: W.W. Norton, New York.

5. Acemoglu et al. (2015) Macroeconomics. Boston, MA: Pearson Education, Inc.

\section{Your next submission with Juniper Publishers will reach you the below assets}

- Quality Editorial service

- Swift Peer Review

- Reprints availability

- E-prints Service

- Manuscript Podcast for convenient understanding

- Global attainment for your research

- Manuscript accessibility in different formats

( Pdf, E-pub, Full Text, Audio)

- Unceasing customer service

Track the below URL for one-step submission https://juniperpublishers.com/online-submission.php 